\title{
Characteristics of Cell Wall Polysaccharides and Their Degrading Enzyme Activities in Mealy Fruit and "Ishinashi" Fruit of Japanese Pear (Pyrus serotina Rehder var. culta Rehder) ${ }^{1}$
}

\author{
Shohei Yamaki, Yoshihiko Sato and Yutaka Machida \\ Fruit Tree Research Station, Ministry of Agriculture, \\ Forestry and Fisheries, Yatabe, Ibaraki 305.
}

\begin{abstract}
Summary
How the cell wall constituents in Japanese pear mealy fruit (Pyrus serotina Rehder culta Rehder, cvs. Chojuro, Kikusui, 92-7, 1-33) and "Ishinashi" fruit (cv. Chojuro) differ from fruit showing hardly both symptoms (cvs. Nijisseiki, Hosui, 93-3) was shown through analyses of cell wall polysaccharides and their constituent monosaccharides, and cell wall-degrading enzyme activities.

Cell wall polysaccharides were fractionated into water-soluble carbohydrate $(9 \sim$ $13 \%$ ), $\mathrm{NaClO}_{2}$-soluble carbohydrate(3 5\%), EDTA-soluble carbohydrate(below $2 \%$ ), acid-soluble hemicellulose (23 39\%), alkali-soluble hemicellulose (16 21\%) and cellulose $(25 \sim 36 \%)$. The polysaccharides were composed of glucose $(35 \sim 43 \%)$, uronic acid $(26 \sim 31 \%)$, xylose $(11 \sim 19 \%)$, arabinose $(8 \sim 13 \%)$, galactose $(4 \sim 7 \%)$, rhamnose $(1 \sim 2 \%)$, mannose (below $1 \%$ ) and fucose (below $1 \%$ ).

In mealy fruit, the degradation of acid-soluble hemicellulose in the middle lamella was more prominent than in the control fruit, with the former showing the higher activity of polygalacturonase. The degradation of the cellulose component in the mealy fruit was restricted compared with the control fruit because the rise in endocellulase (neutral form) activity was suppressed. This suggests that the flesh of mealy fruit consists of a weaker attachment of cells and a more rigid cell wall structure than the control fruit.

In "Ishinashi" fruit, the degradation of acid-soluble hemicellulose and cellulose components was more restricted than in the control fruit. This restriction was also supported by the result that the activities of polygalacturonase, endocellulase and exocellulase were lower than in the control fruit. This suggests that the flesh of the "Ishinashi" fruit contains a tighter attachment of cells and a more rigid cell wall structure than that of the control fruit.

It is suggested that there are some varietal differences in the cellulase and polygalacturonase activities and in the compositions of the cell wall polysaccharides.
\end{abstract}

\section{Introduction}

It is of prime importance in pear fruit to determine the biochemical characteristics of the flesh texture and then to control the texture phytochemically or genetically for long time-preservation of fruit quality. Much has been reported about the alteration of cell wall components or cell wall-degrading

1 Received for publication April 9, 1983.

This report is contribution A-157, Fruit Tree Research Station. enzyme activities, which are greatly related to the fruit texture during the development or ripening of pear fruit $(1,2,9,14,15,16)$. In this connection, however, many other problems remain to be studied, such as mealy breakdown, which often occurs at the overripe stage in some cultivars, and a physiological disorder called "Ishinashi" or "Yuzuhada", which is similar to hard end in 'Bartlett' pear. Through an investigation of the varietal and regional differences of cell wall components of Japanese pear fruit, 
Machida and Tashiro(11) indicated that fruit texture is closely correlated with the amount of cell wall polysaccharide. Machida and Matsui(10) showed that more cell wall polysaccharide occurred in "Ishinashi" fruit than normal fruit. From histochemical observations, Hayashi and Wakisaka(7) suggested that the suberelline which deposited in the cell wall of parenchymal cells increased the hardness of "Yuzuhada" fruit. As for mealy breakdown in apple, Ben-Ari and Kislev(5) observed ultrastructural changes in the cell wall, and suggested the dissolution of the middle lamella in the mealy fruit. Fukuda et al. (6) showed in apples that compresion tests of fruit flesh can distinguish between the mealy fruit and normally softened fruit. However, the biochemical characteristics of both mealy and "Ishinashi" fruits still remain undetermined.

We have already reported on the quantitative and qualitative alterations of cell wall polysaccharides and cell wall-degrading enzyme activities during the development and ripening of Japanese pear fruit $(14,15,16)$. The breakdown of acid-soluble hemicellulose, and the enhancement of polygalacturonase and exocellulase activities were found to play an important role on fruit softening, the influence of alkali-soluble hemicellulose on fruit enlargement, and the decomposition of cellulose and the increase of some hemicellulase activity on cellular deterioration with over-ripening. Damaged fruit flesh appears to result when the normal degradation of cell wall polysaccharides during ripening is altered by some changes in the sequence or in the strength of activation in cell walldegrading enzyme activities. This paper reports the differences in the composition of cell wall polysaccharides and their degrading enzyme activities between mealy or "Ishinashi" fruit and normal fruit.

\section{Materials and Methods}

\section{Materials}

Fruit materials were collected from the orchard of the Fruit Tree Research Station at Hiratsuka. About 50 fruit from each of 'Kikusui', '92-7' and 'イ-33', which tend to be mealy on the tree as well as during storage, were harvested at overripe stage on September 20, September 11 and September 20 in 1977, respectively. The harvested fruit were divided into 2 groups of mealy fruit and the control fruit (showing no symptom). In the case of 'Chojuro', which tends to be mealy or to bear "Ishinashi" fruit, about 100 fruit were harvested on September 13 in 1977, then were divided into 3 groups of mealy fruit, "Ishinashi" fruit and the control fruit (showing neither symptom). On the other hand, as examples of cultivars having no mealy fruit (difficult-to-become-mealy cultivars) or "Ishinashi" fruit (difficultto-become- "Ishinashi” cultivar), 'Hosui', 'Nijjiseiki' and '93-3' were used. Ripe and overripe fruit were harvested on September 13 and September 22, respectively, in 'Hosui' and 'Nijisseiki', and July 30 and August 4, respectively, in '93-3'. From each group, 10 fruit of equal size and equal skin color were selected, and used for experiments.

Cell wall preparation and fractionation

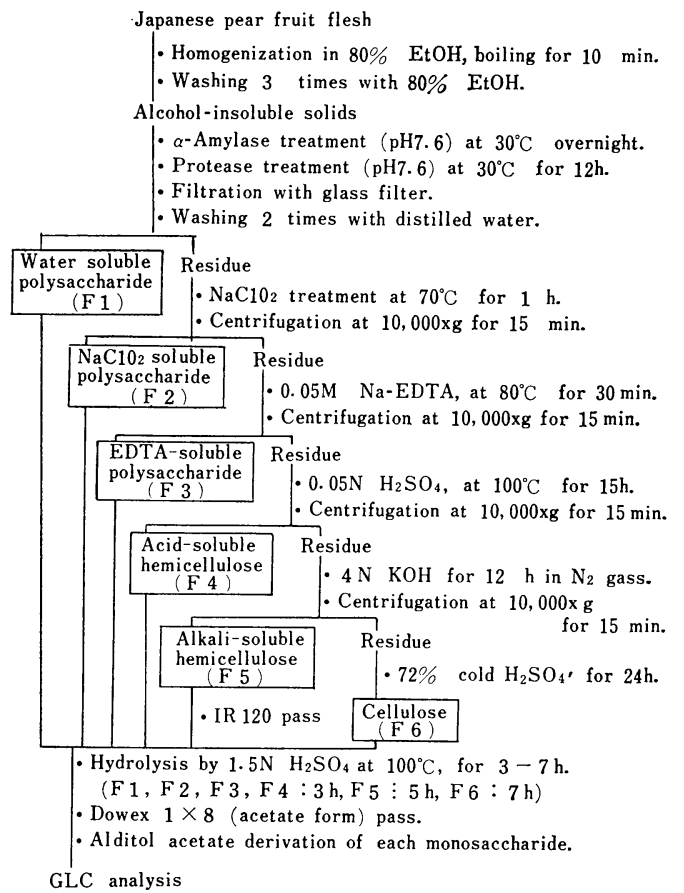

Fig.1. Flow chart of the preparation and fractionation of cell wall polysaccharides and anaylses of monosaccharides contained in each polysaccharide fraction. 
The fractionation of cell wall polysaccharides is shown in the flow chart of Fig. 1(15).

Gas chromatographic analysis of alditol acetate of monosaccharides and calculation of the amount of each polysaccharide fraction

Polysaccharide fractions were hydrolyzed in $1.5 \mathrm{~N} \mathrm{H}_{2} \mathrm{SO}_{4}$ at $100^{\circ} \mathrm{C}$ for $3 \mathrm{~h}$ (for fraction $1,2,3$ and 4 ), $5 \mathrm{~h}$ (for fraction 5 ) and $7 \mathrm{~h}$ (for fraction 6). The hydrolyzates were passed through Dowex $1 \times 8$ (acetate form) to remove $\mathrm{SO}_{4}{ }^{2-}$, and lyophilized. Before hydrolysis, an aliquot of each fraction was analyzed for uronic acid by the carbazol method(12). Dried monosaccharides of each fraction after hydrolysis were reduced with sodium borohydride to form the corresponding alditols, which were acetylated by heating with acetic anhydride for $3 \mathrm{~h}$ at $121^{\circ} \mathrm{C}$ according to Albersheim's method(3). Gas chromatographic separation was carried out on a glass column $(3 \mathrm{~mm} \times 1.5 \mathrm{~m})$ packed with Gaschrom p (100 120 mesh) coated with $0.2 \%$ polyethyleneglycol succinate, 0.2 $\%$ polyethyleneglycol adipate and $0.4 \%$ silicon XF-1150. The column temperature at injection was $120^{\circ} \mathrm{C}$. This was maintained for $10 \mathrm{~min}$ after injection, and then was raised to $180^{\circ} \mathrm{C}$ at a rate of $1^{\circ} \mathrm{C}$ per min. The temperature of the injection and detection ports was kept at $210^{\circ} \mathrm{C}$. The amount of each polysaccharide fraction was expressed as the sum of the amounts of monosaccharides obtained by hydrolyzation and the amount of uronic acid(15).

\section{Enzyme preparation}

Cellulase and polygalacturonase were extracted by grinding the fleshy tissue in a homogenizer with $0.05 \mathrm{M}$ phosphate buffer $(\mathrm{pH}$ 7.3) containing $0.1 \%$ potassium ascorbate and polyclar AT corresponding to $10 \%$ of the fresh weight. The homogenate was passed through 4 layers of gauze. The residue was resuspended in $2 \mathrm{M} \mathrm{NaCl}$, stirred for $30 \mathrm{~min}$, and filtered again. The filtrates were pooled and centrifuged at $10,000 \times g$ for 15 min. The supernatant was dialyzed against distilled water overnight. The dialyzate was lyophilized, then dissolved in a little distilled water and dialyzed again. The resultant solution was used as the enzyme sample. Hemicellulose-degrading enzymes (xylanase, arabanase, $\beta$-xylosidase, $\beta$-glucosidase and $\beta$-galactosidase) were extracted by grinding fleshy tissue in a homogenizing medium of $0.05 \mathrm{M}$ potassium phosphate buffer $(\mathrm{pH} 7.3)$ containing $0.1 \%$ potassium ascorbate and 10 $\mathrm{mM}$ mercaptoethanol. The homogenate was centrifuged at $10,000 \times g$ for $15 \mathrm{~min}$. The supernatant and pellet were separately dialyzed against water overnight. The pellet suspension was analyzed for bound enzymes. The supernatant was lyophilized, then dissolved in a little distilled water and dialyzed again. The resultant solution was analyzed for soluble enzymes. All of the above procedures were carried out at $4^{\circ} \mathrm{C}$.

Enzyme assay

Cellulase ( $\beta$-1, 4-glucan 4-glucanohydrolase EC 3.2.1.4) activity was assayed by the reduction of viscosity for endocellulase, and by determining reducing sugar released in a reaction medium containing $1 \% \mathrm{CMC}$ as a substrate. Polygalacturonase (Poly- $\alpha-1,4-$ galacturonide glycanohydrolase EC 3.2.1.15) activity was determined by measuring reducing sugar released from polygalacturonate as a substrate. The details of the assays of the activities of these 2 enzymes were described in a previous paper(16).

Xylanase $(\beta-1,4$-xylan xylanohydrolase EC 3.2.1.8) and arabanase activities were determined by measuring the reducing sugar released from xylan and araban of substrates, respectively, as described in a previous paper (14). The assays for $\beta$-xylosidase $(\beta$-xyloside xylohydrolase EC 3.2.1.37), $\beta$-galactosidase $(\beta$-D-galactoside galactohydrolase EC 3.2.1. $23)$ and $\beta$-glucosidase ( $\beta$-D-glucoside glucohydrolase EC 3.2.1.21) activities were carried out by determining the amount of $\mathrm{p}$-nitrophenol released from $\mathrm{p}$-nitrophenyl- $\beta$-xylopyranoside, $\quad \mathrm{p}$-nitrophenyl- $\beta$-galactopyranoside and $\mathrm{p}$-nitrophenyl- $\beta$-glucopyranoside of substrates, respectively, as described in a previous paper (14). The activities were expressed as total of the soluble and bound enzyme activities.

Ground-color and hardness

The ground-color of the fruit skin was 
measured by a color chart devised in the Fruit Tree Research Station (17). The hardness of the fruit flesh was determined by a Universal hardness meter.

\section{Results}

Maturity of mealy and "Ishinashi" fruits Fruit of each cultivar were harvested at the full ripe to overripe stage and selected as described above. The values of the groundcolor of the skin, flesh hardness and fruit weight are shown in Table 1. All of the typical mealy fruit ('Chojuro', 'Kikusui', '92-7' and ' $イ-33$ ') had low values for flesh hardness and typically less juciness compared with the control fruit. The value of the

Table 1 Maturity of fruit materials tested.

\begin{tabular}{|c|c|c|c|c|c|c|c|c|c|c|c|c|c|}
\hline \multirow{2}{*}{$\begin{array}{l}\text { Maturity } \\
\text { attribute }\end{array}$} & \multicolumn{3}{|c|}{ Chojuroz $^{z}$} & \multicolumn{2}{|c|}{ Kikusui } & \multicolumn{2}{|c|}{$92-7$} & \multicolumn{2}{|c|}{ イ-33 } & \multicolumn{2}{|c|}{ Nijisseiki } & \multicolumn{2}{|c|}{ Hosui } \\
\hline & $\mathrm{C}^{\mathrm{y}}$ & $\mathrm{M}^{\mathrm{x}}$ & $I^{w}$ & $\mathrm{C}$ & $\mathrm{M}$ & $\mathrm{C}$ & M & $\mathrm{C}$ & M & $\mathrm{R}^{\mathrm{v}}$ & $\mathrm{OR}^{\mathrm{u}}$ & $\mathrm{R}$ & OR \\
\hline Ground-color & 5.2 & 5.7 & 5.3 & 4.3 & 4. 6 & 3.5 & 3.9 & 4.1 & 4.8 & 4.3 & 5.0 & 4.5 & 5.3 \\
\hline Hardness (kg) & 1.09 & 0.79 & 1.36 & 0.49 & 0.37 & 0.50 & 0.38 & 0.77 & 0.47 & 0.50 & 0.50 & 0.54 & 0.48 \\
\hline $\begin{array}{l}\text { Fresh weight } \\
(\mathrm{g})\end{array}$ & 324 & 305 & 345 & 250 & 274 & 263 & 267 & 262 & 262 & 298 & 292 & 391 & 410 \\
\hline
\end{tabular}

z 'Chojuro', 'Kikusui', '92-7' and 'イ-33', are easy-to-become-mealy cultivars while 'Nijisseiki' and 'Hosui' are difficult-to-become-mealy (and-"Ishinashi”) cultivars, respectively. 'Chojuro' is also an easy-to-become-"Ishinashi" cultivar.

y Control fruit, ${ }^{x}$ Mealy fruit, w "Ishinashi" fruit, ${ }^{\mathrm{v}}$ Ripe fruit, " Overripe fruit.

$\mathrm{y}, \mathrm{x}$ and ${ }^{\mathrm{w}}$ were harvested simultaniously at the overripe stage, and ${ }^{\mathrm{v}}$ and ${ }^{\mathrm{u}}$ were harvested at the ripe and overripe stages, respectively.

Table 2 Cell wall-degrading enzyme activities (unit/gFW) varying with cultivars and with disorders or maturities.

\begin{tabular}{|c|c|c|c|c|c|c|c|c|c|c|c|c|}
\hline \multirow{2}{*}{ Enzyme } & \multirow{2}{*}{$\mathrm{C}^{\mathrm{z}}$} & \multicolumn{2}{|c|}{ Chojuro } & & & \multicolumn{3}{|c|}{ Kikusui } & \multicolumn{3}{|c|}{$92-7$} & \multirow[b]{2}{*}{$\mathrm{M} / \mathrm{C}$} \\
\hline & & $\mathrm{M}$ & I & $\mathrm{M} / \mathrm{C}$ & $\mathrm{I} / \mathrm{C}$ & $\mathrm{C}$ & $\mathrm{M}$ & $\mathrm{M} / \mathrm{C}$ & & $\mathrm{C}$ & $\mathrm{M}$ & \\
\hline Xylanase & 103 & 147 & 318 & 1.48 & 3.09 & 288 & 537 & 1.86 & & 243 & 291 & 1.13 \\
\hline Arabanase & 152 & 227 & 536 & 1. 49 & 3.53 & 143 & 285 & 1.99 & & 559 & 709 & 1. 27 \\
\hline$\beta$-xylosidase & 101 & 134 & 103 & 1. 32 & 1.02 & 199 & 246 & 1. 24 & & 92 & 146 & 1.59 \\
\hline$\beta$-glucosidase & 14 & 17 & 16 & 1.21 & 1. 14 & 28 & 33 & 1.18 & & 34 & 38 & 1. 12 \\
\hline$\beta$-galactosidase & 493 & 431 & 444 & 0.87 & 0.90 & 626 & 652 & 1.04 & & 603 & 596 & 0.94 \\
\hline \multicolumn{13}{|l|}{ Endocellulase ${ }^{\mathrm{y}}$} \\
\hline Acid form ${ }^{z}$ & 33 & 38 & 18 & 1.15 & 0.47 & 452 & 732 & 1.62 & \multicolumn{3}{|c|}{196} & 1.50 \\
\hline Neutral form ${ }^{\mathrm{y}}$ & 39 & 27 & 4 & 0.69 & 0.10 & 408 & 351 & 0.86 & \multicolumn{2}{|r|}{185} & 64 & 0.35 \\
\hline Exocellulase & 4.7 & 8.7 & 3.3 & 1.85 & 0.70 & 59 & 71 & 1.20 & \multicolumn{2}{|r|}{31} & 34 & 1. 10 \\
\hline Polygalacturonase & 8.2 & 13.3 & 3.1 & 1.62 & 0.38 & 18 & 28 & 1.56 & & 34 & 43 & 1.26 \\
\hline \multirow{2}{*}{ Enzyme } & \multicolumn{4}{|c|}{ イ -33} & \multicolumn{4}{|c|}{ Nijisseiki } & \multicolumn{4}{|c|}{ Hosui } \\
\hline & $\mathrm{C}$ & $\mathrm{M}$ & & $\mathrm{M} / \mathrm{C}$ & $\mathrm{R}$ & OR & $\mathrm{OR} /$ & & $\mathrm{R}$ & & & $\mathrm{OR} / \mathrm{R}$ \\
\hline Xylanase & 230 & 261 & & 1. 13 & 488 & 542 & 1. 11 & & 146 & & & 1.15 \\
\hline Arabánase & 533 & 537 & & 1.01 & 388 & 233 & 0.60 & & 246 & & & 1.35 \\
\hline$\beta$-xylosidase & 62 & 76 & & 1.23 & 104 & 114 & 1.10 & & 30 & & 1 & 2.03 \\
\hline$\beta$-glucosidase & 14 & 16 & & 1. 14 & 32 & 45 & 1.41 & & 10 & & 21 & 2.10 \\
\hline$\beta$-galactosidase & 150 & 156 & & 1.04 & 602 & 681 & 1. 13 & & 410 & & & 1.82 \\
\hline Endocellulase & & & & & & & & & & & & \\
\hline Acid form ${ }^{y}$ & 39 & 42 & & 1.08 & 296 & 299 & 1.01 & & 200 & & & 1.88 \\
\hline Neutral form ${ }^{y}$ & 74 & 12 & & 0.16 & 280 & 289 & 1.03 & & 251 & & & 1.52 \\
\hline Exocellulase & 93 & 124 & & 1.33 & 29 & 39 & 1.34 & & 163 & & 50 & 0.31 \\
\hline Polygalacturonase & 139 & 201 & & 1.45 & 33 & 30 & 0.9 & & 286 & & 45 & 0.16 \\
\hline
\end{tabular}

$z$ As to symbols, refer to Table 1 .

y milli unit/gFW 
ground-color in the former was merely slightly higher than that in the latter and there was no difference in fresh weight between them. On the other hand, the flesh hardness of 'Nijisseiki' and 'Hosui' fruit, which were juicy and hardly mealy even at the overripe stage, was only slightly reduced in the overripe fruit compared with ripe fruit, although the ground-color of the overripe fruit strongly changed from green to yellow. Since mealy breakdown is considered to appear at the overripe stage, this suggests that mealy fruit is produced by other processes of softening compared with the softening of fruit in difficult-to-become-mealy cultivars. The flesh of "Ishinashi" fruit was distinctly harder than that of the control fruit. However, there was no difference in the ground-color or the fruit weight between the 2 fruits. Thus, "Ishinashi" fruit appears to be produced by the lack of normal softening with ripening.

Alterations in cell wall-degrading enzyme acitivities

It is considered that the softening of the flesh in mealy fruit and the abnormal hardness of the flesh in "Ishinashi" fruit depend upon some alteration in the attachmentstrength among cells and/or in the thickness and rigidity of the cell wall. Consequently, some cell wall-degrading enzymes are supposed to play an important role in determining the particular texture. As shown in Table 2 , endocellulase (neutral type) activity in typical mealy fruit of the 4 easy-to-becomemealy cultivars was markedly lower than that in the control fruit (not mealy), and polygalacturonase activity was apparently higher. On the other hand, 'Hosui' and 'Nijisseiki' tended to show an increase in endocellulase activity and an decrease in polygalacturonase activity with overripening. Although exocellulase activity was also higher in mealy fruit than in the control fruit in the 4 easy-to-become-mealy cultivars, this tendency was not particular to mealy fruit, because a similar increase was detected in 'Nijisseiki' overripe fruit, too. Some hemicellulase (xylanase, arabanase, $\beta$-xylosidase, $\beta$-glucosidase and $\beta$-galactosidase) activities also changed greatly. Such changes, however, were not a characteristic feature of mealy fruit.

In the case of "Ishinashi" fruit, the activities of endocellulase (acid and neutral types), exocellulase and polygalacturonase were clearly lower than in the control fruit (Table 2 ), and consequently, the degradation of cellulose and pectic substances of cell wall seemed to be suppressed. On the other hand, xylanase and arabanase activities were about 3 times higher than in the control fruit. However, no difference was found in the activities of the other hemicellulases.

Enzyme activities of the control fruit differed with cultivars, and it was especially true for endocellulase, exocellulase and polygalacturonase (Table 2). The endocellulase activity in 'Kikusui' was about 10 times higher than that in 'Chojuro' or ' $\nmid-33$ '. The activities of exocellulase and polygalacturonase were both 35 times higher in 'Hosui' and 20 and 17 times higher in ' $1-33$ ', respectively, than those in 'Chojuro'. However, the varietal differences of each hemicellulase activity were less than for the other enzyme activities.

Alterations in cell wall polysaccharides and monosaccharides

It is expected that the quantity or quality of cell wall polysaccharides of mealy or "Ishinashi" fruit is different from that of the control fruit, considering the differences in enzyme activities. The cell wall polysaccharides were divided into 6 fractions; water-soluble polysaccharide (F 1), $\mathrm{NaClO}_{2}$ soluble polysaccharide (F 2), EDTA-soluble polysaccharide (F 3), acid-soluble hemicellulose (F 4), alkali-soluble hemicellulose (F 5), and cellulose (F 6). The polysaccharides were composed of major monosaccharides (glucose, uronate, galactose, xylose, arabinose) and minor ones (rhamnose, fucose, mannose). Some differences were recognized in both the total polysaccharide amount and the monosaccharide composition among the control fruits of all cultivars (Table 3). For instance, the total polysaccharide amount was highest in 'Chojuro', which had the hardest fruit flesh. Regarding the mono- 
Table 3 Monosaccharide compositions of cell wall polysaccharides and their fractions in some cultivars ${ }^{2}$.

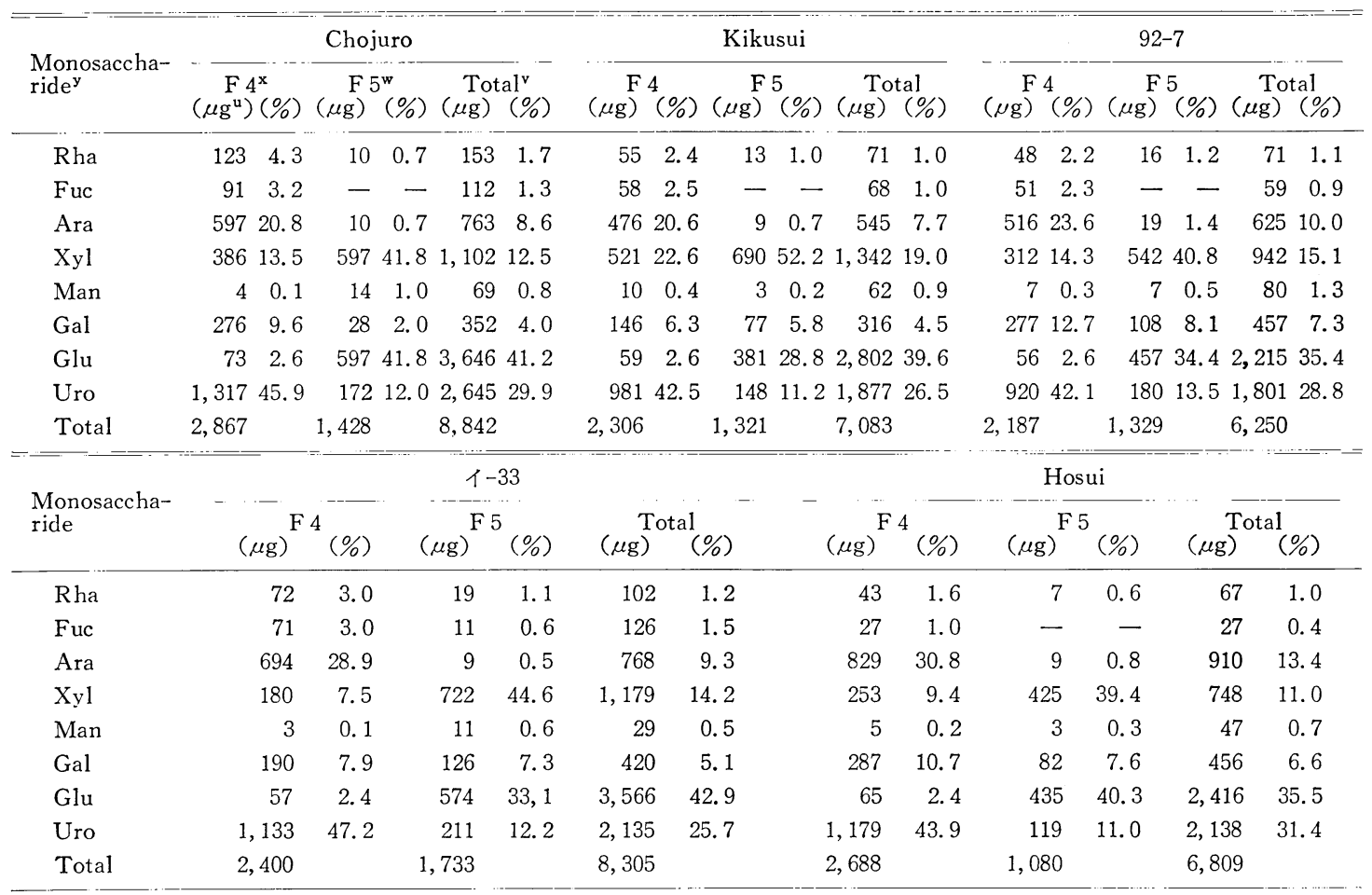

Fruit were harvested at the overripe stage.

y Rha : rhamnose, Fuc:fucose, Ara : arabinose, Xyl :xylose, Man : mannose, Gal : galactose, Glu : glucose, Uro : uronate.

$x$ Acid-soluble hemicellulose.

w Alkali-soluble hemicellulose.

$v$ The sum of F 1 to F 6 .

u The amount on $\mathrm{g}$ fresh weight basis.

saccharide composition of the total polysaccharides, the ratios of xylose in 'Kikusui' and galactose in ' $92-7$ ' in total monosaccharides were comparatively higher than those in the other cultivars. Acid-soluble hemicellulose (F 4) was composed mainly of arabinose, uronate, xylose and galactose, with arabinose and uronate contents dominant. The ratio of arabinose to xylose in this fraction was different with cultivars, such as, about 4 in ' $1-33$ ' versus about 1 in 'Kikusui'. In the alkali-soluble hemicellulose (F 5), xylose and glucose were the dominant monosaccharides, and the presence of xyloglucan was suggested. The ratio of xylose to glucose in this fraction differed also with cultivars, and it was higher in 'Kikusui' $(\fallingdotseq 2)$ than the others $(\fallingdotseq 1 \sim 1.2$ ). However, from the above results, it was difficult to establish correlations between the amount or compoositin of polysaccharides and their constituent monosaccharides, and fruit texture.

Cell wall polysaccharides were composed of $\mathrm{F} 4, \mathrm{~F} 5$ and $\mathrm{F} 6$ as main components and $\mathrm{F} 1, \mathrm{~F} 2$ and $\mathrm{F} 3$ as minor ones regardless of cultivars. As for 'イ-33', '92-7' and 'Kikusui', the amounts of $\mathrm{F} 4$ were lower in mealy fruit than in the control fruit, although for 'Chojuro' the reverse was true (Fig. 2). However, the amounts of F 5, F 6 and total polysaccharides were higher in the above 4 easy-to-become-mealy cultivars. In the case of 'Ishinashi' fruit, the amounts of all polysaccharide fractions showed higher values than in the control fruit. For '93-3' and 'Hosui', the amounts of F 4, F 6 and total 

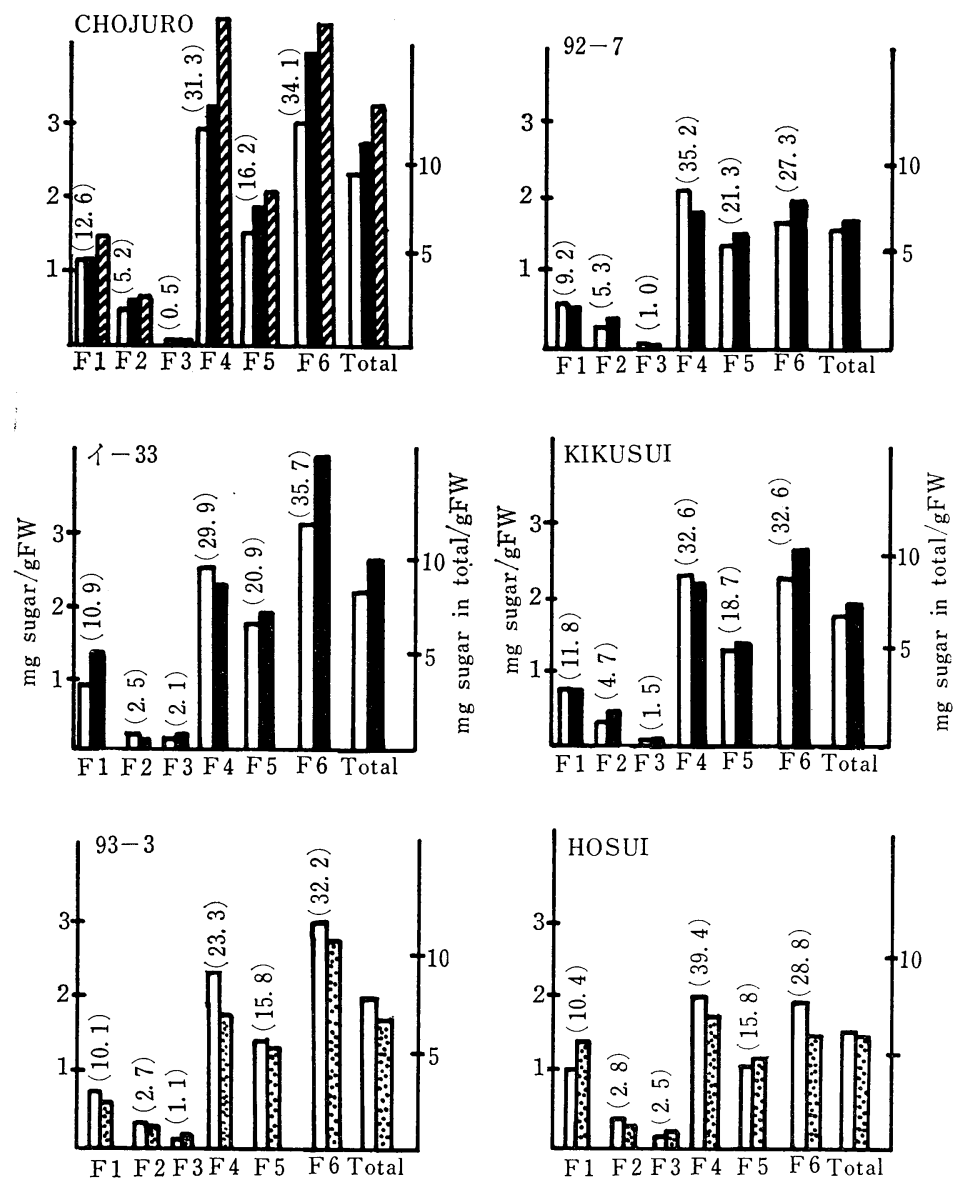

Fig.2. Amounts of cell wall polysaccharide fractions varying with cultivars and with disorders or maturities.

The figures in the brackets show the amounts of respective polysaccharide fractions in per cent of that of the total polysaccharides. In 'Chojuro', 'Kikusui' ' $92-7$ ' and 'イ-33', fruit were harvested at overripe stage. $\square, \mathbf{\square}$ and ${ }^{2}$ indicate the control fruit, mealy fruit and 'Ishinashi” fruit, respectively. In '93-3' (a difficalt-to-become-mealy cultivur) and 'Hosui', $\square$ and $\square$ express ripe and overripe fruit, respectively. The values of '933 ' and 'Hosui' were quoted from the previous papers (13) and (15), respectively. F 1, F 2, F 3, F 4, F 5 and F 6 expressed water-soluble polysaccharide, $\mathrm{NaClO}_{2}$-soluble polysaccharide, EDTA-soluble polysaccharide, acid-soluble hemicellulose, alkali-soluble hemicellulose and cellulose, respectively.

polysaccharides decreased with overripening, although the decrease in F 5 was small (Fig. 2). In the present study, however, polysaccharide amount based on fresh weight does not always reflect the amount per cell, because the cell number per $g$ fresh weight of mealy (or "Ishinashi") fruit is possibly different from that of the control fruit due to the differences in the flesh density. We have already reported that the amount of
F 5 per cell in 'Hosui' fruit was almost constant during ripening, while those of $\mathrm{F} 4$ and F 6 changed drastically(15). The tendency that the amount $\mathrm{F} 5$ was difficult to change compared with those of F 4 and F 6 was shown in the case of the watercored Japanese pear fruit, although on $\mathrm{g}$ fresh basis (13). Moreover, in the present study, the amounts of $\mathrm{F} 5$ based on $\mathrm{g}$ fresh weight in mealy fruit in the 4 easy-to-become-mealy 

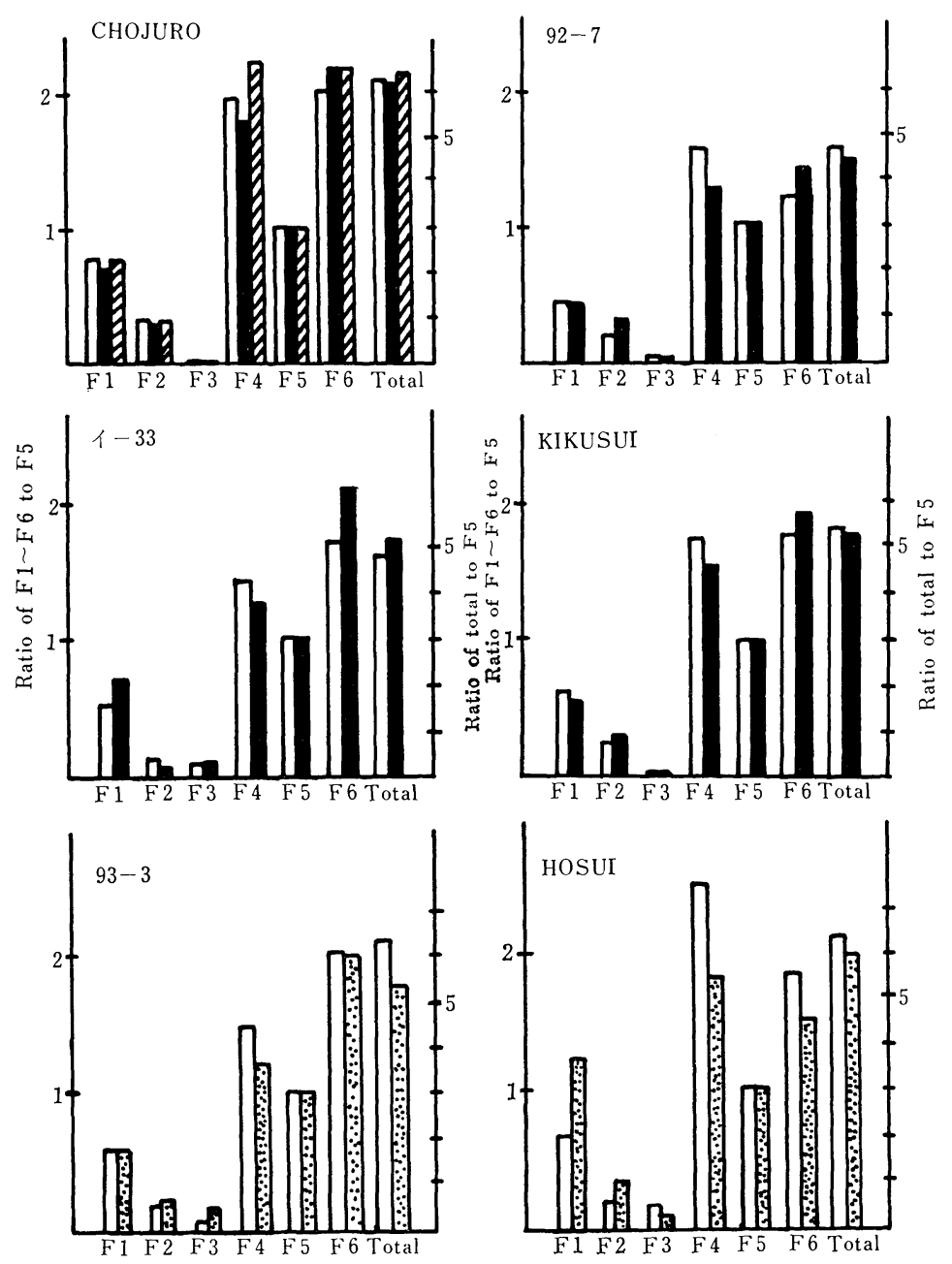

Fig.3. Relative amounts of cell wall polysaccharide fractions to $\mathrm{F} 5$ varying with cultivars and with disorders or maturities.

As to symbols, refer to Fig. 1

cultivars were only a little higher than those in the control fruit, while the amounts of F 4 and F 6 differed greatly between them. Thus, the amount of F 5 per cell seems to be held roughly constant even during some cell wall alterations with ripening. The amount of each polysaccharide fraction, therefore, was expressed as the ratio to that of $\mathrm{F} 5$ as shown in Fig. 3. In easy-to-becomemealy cultivars, the ratio was lower for $\mathrm{F} 4$ but higher for $F 6$ in the mealy fruit than the control fruit, although it did not differ for the total polysaccharides between them. This suggests that the acid-soluble hemicellulose (F 4) in the cell walls of mealy fruit is more degraded than that in the control fruit, while cellulose degradation is rather restricted. In the case of "Ishinashi" fruit, the amounts of F 4, F 6 and total polysaccharides were greater than in the control fruit (Fig. 3). This suggests that the degradation of both the acid-soluble hemicellulose and the cellulose in the cell walls was very restricted in "Ishinashi" fruit. 
As to 'Hosui' or '93-3', which hardly showed symptoms of mealy breakdown or "Ishinashi" at 2 harvest dates, the situation was different. In 'Hosui', the amounts of F $4, F 6$ and total polysaccharides decreased, while that of F1 increased clearly with ripening. A similar tendency was also noticed in the fruit of ' $93-3$ ' except for the amount of $\mathrm{F} 1$.

\section{Discussion}

In the present experiment using mealy fruit, it was very difficult to decide what cultivars or what degree of fruit maturity should be chosen as the control. Since mealy breakdown appears in the process of overripening, it contains both of the changes caused by mealy breakdown per se and those induced by overripening. First, as the control, we used fruit which showed hardly any symptoms of mealy breakdown although harvested simultaniously with mealy fruit. However, there is a possibility that the difference between the mealy and control fruit might only represent a difference in maturity. Thus, the comparison between ripe and overripe fruit of difficult-to-becomemealy cultivars were needed as another control. On the other hand, fruit of cultivars suffering from "Ishinashi" showed the symptom even during immature stage. So, "Ishinashi" fruit are considered to be abnormally developed fruit and can be easily discriminated from the control fruit.

Alterations in the cell wall polysaccharides during fruit softening

The author has already reported that alterations in cell eall polysaccharides and their degrading enzyme activities developed with ripening and overripening in Japanese pear fruit(14.15). A loss of arabinose and galactose from acid soluble-hemicellulose characterized fruit softening. Water-soluble pectin increased with ripening due to activation mainly of polygalacturonase. The cellulose component was also degraded with overripening, probably depending upon a rise of endocellulase activity. On the other hand, xylose and non-cellulosic glucose in alkalisoluble hemicellulose did not alter with ripening and overripening. In the softening process of pear fruit, Ahmed and Labavitch $(1,2)$ indicated that galactose and arabinose were lost from the cell wall. Furthermore, a considerable loss of galactose and only a small loss of arabinose were observed in the cell walls of ripe apple fruit, although xylose and non-cellulosic or cellulosic glucose remained constant (4. 8).

In general, the cell wall structure of the fruit flesh cell can be explained based on the ordinary model. That is, the cell wall consists of the middle lamella depositing mainly pectic substances, and the primary cell wall composed mainly of cellulose and hemicellulose with a small amount of pectic substances. In the case of the stone cell, the secondary cell wall develops and deposits much lignine component. Thus, in the present experiment, acid-soluble hemicellulose (F 4) composed mainly of uronate, arabinose and galactose seemed to be located in the middle lamella or the outer cell wall, and served to bind cells to each other. On the other hand, a great amount of alkalisoluble hemicellulose composed mainly of xylan and glucan (F 5) seemed to be located in the inner cell wall, with cellulose fibers (F 6) orientated regularly. According to this model of cell wall structure, the fruit will be moderately soften by both loosening of the cellular attachment following the partial degradation of acid-soluble hemicellulose and decrease in the thickness or rigidity of the cell wall following the degradation of cellulose fiber.

Characteristics of cell wall polysaccharides in mealy fruit

The amount of acid-soluble hemicellulose in mealy fruit was more reduced than that in the control fruit. However, this hemicellulose was reported to decrease gradually with ripening and overripening in 'Hosui' (15) and '93-3' (13), which were difficult-tobecome-mealy cultivars. So, the degradation of acid-soluble hemicellulose is a common characteristic of Japanese pear fruit when they ripened and became soft, but not a specific characteristic of mealy fruit. However, polygalacturonase activity in mealy 
fruit was held in a higher level than that in the control fruit, while this activity in overripe fruit in difficult-to-become-mealy cultivars did not increase more than of just ripe fruit, and rather decreased. These results show that the degradation of pectic substances in the middle lamella is more prominent in the mealy fruit than in the control fruit, and consequently the flesh hardness of mealy fruit is more markedly reduced than that of the control fruit. On the other hand, the degradation of cellulose fiber in the mealy fruit was restricted compared with the control fruit, despite the fact that the cellulose fiber was clearly degraded in the overripe fruit of 'Hosui' (15) or '93-3'(13). This restriction of degradation is also indicated by the fact that the activity of endocellulase (neutral form) in mealy fruit was held at a lower level. These results show that the structure of cell wall itself is held more rigid in mealy fruit than the control fruit.

From the above events, we assumed why some ripe fruit of Japanese pear tasted mealy. In general, it will be considered that the relative difference between the resistance to pulling the cells apart and that against breaking the cell wall probably causes organoleptic differences. In the case of mealy fruit, fruit flesh, in which cells can slip easily past each other due to the weakness in attachment forces caused by the more degradation of acid-soluble hemicellulose and cell wall is difficult to break due to the more rigid structure caused by the restriction of cellulose degradation, probably tastes mealy and juiciless. Further biochemical and physical studies are required to clarify the processes during ripening and overripening in Japanese pears.

Characteristics of cell wall polysaccharides in "Ishinashi" fruit

In "Ishinashi" fruit, the degradation of acid-soluble hemicellulose and cellulose components was apparently restricted compared with the control fruit, as described previously by Machida and Matsui(10). This restriction was evidenced in the present study by the lower activities of polygalac- turonase, endocellulase and exocellulase in "Ishinashi" fruit than in the control fruit. Apparently, "Ishinashi" fruit remain in the immature state by suppression of the rise in cell wall-degrading enzyme activities. However, xylanase and arabanase activities drastically rose in "Ishinashi" fruit, despite the fact that their activities in the immature fruit in difficult-to-become-"Ishinashi" cultivars are lower than those in ripe fruit. It is not clear why these enzyme activities increased, but this suggests that the structure of the cell wall polysaccharides in "Ishinashi" fruit might not be similar to that in the immature control fruit. The early symptoms of "Ishinashi" fruit are known in experiences to appear at the immature stage before the cell wall-degrading enzyme activities increase. So, some unusual alterations of the cell wall polysaccharides might occur not only in the cell wall-degradation in ripening fruit, but also in the cell wall-generation in immature fruit. "Ishinashi" fruit are probably very hard because the attachment of cells is tight due to less breakdown of the acid-soluble hemicellulose of the middle lamella, and also because the cell wall structure remain rigid due to the lack of degradation of the cellulose component of the inner cell wall.

Finally, it should be noticed that some varietal differences were found in the activities of cellulase and polygalacturonase and in the composition of the cell wall polysaccharides. However, it is not clear how the strength of these enzyme activities and the type of polysaccharide constituent are characterized in mealy or "Ishinashi" cultivars. In the future, we will be able to elucidate the causal mechanism of the occurrence of these abnormal fruits and the varietal difference by inverstigating in detail the properties of the cell wall-degrading enzymes and the molecular weights and the sugar sequences of the main and side chains of cell wall polysaccharides.

\section{Acknowledgement}

The authors express their sincere thanks to Dr. T. Yamazaki, the Fruit Tree Research 
Station for his helpful discussion and encouragement, and to all members of their laboratories for their useful advices.

\section{Literature cited}

1. Ahmed, A. E. and J. M. Labavitch. 1980. Cell wall metabolism in ripening fruit. 1. Cell wall changes in ripening "Bartlett" pears. Plant Physiol. 65 : 1009-1013.

2. Ahmed, A. E. and J. M. Labavitch. 1980. Cell wall metabolism in ripening fruit. II. Changes in carbohydrate-degrading enzymes in ripening "Bartlett" pears. Plant physiol. 65 : $1014-1016$.

3. Albersheim, P., D. J. Nevins, P. D. ENGLish and A. KARR. 1967. A method for the analysis of sugars in plant cell-wall polysaccharides by gas-liquid chromatography. Carbohyd. Res. 5 : $340-345$.

4. BARTLEY, I. M. 1976. Changes in the glucans of ripening apples. Phytochem. $15: 625-626$.

5. BEN-ARIE, R. and N. KISLEV. 1979. Ultrastructural changes in the cell walls of ripening apple and pear fruit. Plant Physiol. $64: 197-202$.

6. FukUdA, H., K. ChibA and T. KubOTA. 1980. Changes in texture properties of apple fruit by softening or the onset of mealiness. I. Relationship of universal testing machine parameters and Magness-Taylor fruit pressure tester reading to fruit softening. Bull. Fruit Tree Res. Stn. C. $7: 33-47$.

7. HAYASHI, S. and I. WAKISAKA. 1957. Studies on "yuzuhada" disorder of fruits of Nijisseiki pear (Pyrus serotina). III. Histological observation of the affected fruits. J. Japn Soc. Hort. Sci. 26 : 178-184.

8. KNEE, M. 1973. Polysaccharide changes in cell walls of ripening apples. Phytochem. $12: 1543-1549$.

9. LABAVITCH, J. M. 1981. Cell wall turnover in plant development. Ann. Rev. Plant Physiol.
$32: 385-406$.

10. Machida, Y. and H. Matsui. 1970. Study of cell wall components of fruit flesh in Japa* nese pear. II. Cell wall components in Ishinashi and Yuzuhada-fruit. Agriculture and Hoeticulture. $45: 377-378$.

11. MACHIDA, Y. and T. TASHIRO. 1968. Studies on the texture of pear fruit. II. Factors responsible for the texture in Japanese pear varieties. Part II Cell wall substances. Bull. Hort. Res. Sta., Japan, Ser. A, No. 7 : 93-110.

12. МССоMB, E. A. and MCCready, R. M. 1952. Colorimetric determination of pectic substances. Analytical Chemistry. $24: 1630-$ 1632.

13. YAMAKI, S. and I. KAJIURA. 1983. Watercore in Japanese pear. IV. Changes in polysaccharides and their monosaccharides of cell wall, and some cell wall-degrading enzyme activities. J. Japan Soc. Hort. Sci. in press.

14. YAMAKI, S. and N. KAKIUCHI. 1979. Changes in hemicellulose-degrading enzymes during development and ripening of Japanese pear fruit. Plant \& Cell Physiol. 20:301-309.

15. YAMAKI, S., Y. MACHIDA and N. KAKIUCHI. 1979. Changes in cell wall polysaccharides and monosaccharides during development and ripening of Japanese pear fruit. Plant \& Cell Physiol. 20 : $311-321$.

16. YAMAKI, S. and K. MATSUDA. 1977. Changes in the activities of some cell wall-degrading enzymes during development and ripening of Japanese pear fruit (Pyrus serotina Rehder var. culta Rehder). Plant \& Cell Physiol. $18: 81-93$.

17. YAMAZAKI, T. and K. SUZUKI. 1980. Color charts: Useful guide to evaluate the fruit maturation. I. Colorimetric specifications of color charts for Japanese pear, apple, peach, grape, kaki and citrus fruits. Bull. Fruit Tree Res. Stn. A. $7: 19-44$. 


\section{ニホンナシのボケ症状果, 石ナシ果における細胞壁多糖類及び 細胞壁分解醭素活性の特徵 \\ 山木昭平・佐藤義彦・町田 裕 農林水産省果樹試験場 305 茨城県谷田部町}

\section{摘 要}

ニホンナシにおいてボケ症状となる果実（長十郎，菊 水，92-7，イ-33)，及び石ナシとなる果実（長十郎）の 細胞壁成分が，それらの症状を顕著に示さない果実（二 十世紀，豊水，93-3）とどのように異なるかを，細胞壁 多糖類, その構成単糖類及び細胞壁分解酵素活性の変化 に基ついて検討した。

ナシ果実の細胞壁多桾類は, 水溶性多糖類 (9～13\%), 次亜塩素酸ナトリウム可溶性多桾類 $(3 \sim 5 \%)$, EDTA可溶性多桾類 ( $2 \%$ 以下), 酸可溶性へミセルロース (23 〜39\%)，アルカリ可溶性へミセルロース（16２1\%), セルロース (25〜36\%) から構成されており，末た細胞 壁の構成単糖類はグルコース (35〜 43\%)， ウロン酸 ( 26 〜31\%), キシロース (11 19\%)， アラビノース (8〜 $13 \%)$, ガラクトース (4〜7\%), ラムノース (1〜2\%), マンノース ( $1 \%$ 以下), フュース ( $1 \%$ 以下) からなっ ていた.

ボケ症状果に打ける細胞壁中間層の酸可溶性へミセル ロース成分は，対照果（同一品種でボケていない）ょり
もより分解されていた，この現象は，ボケ症状果に打け るポリガラクチュロナーゼ活性がより高いことからも支 持された，一方，ボケ症状果におけるセルロース成分の 分解はむしろ抑制されていた。これは，ボケ症状果に拉 いてェンドセルラーゼ（中性型）活性が低いこととも一 致した．以上の事実より，ボケ症状果の果肉は対照果の それに比べて，細胞同士の接着が弱く，逆により強固な 細胞壁構造を持つことが示唆された.

石ナシ果において，酸可溶性へミセルロース，セルロ 一ス成分の分解は対照果よりも少なかった．この抑制は, 症状果法护孚る゚゚リガラクチュロナーゼ，エンドセルラ 一ゼ，エキソセルラーゼ活性が，対照果よりも低い結果 とも一致した.このことより, 石ナシ果の果肉はょり強 い細胞同士の接着，より強固な細胞壁構造を維持してい ることが示唆された。

品種間差に関しては，セルラーゼ，ポリガラクチュロ ナーゼ活性の強さ：さらには各多糖類組成にかなりの違 いのあることが示唆された。 